\title{
Lethal effect of high concentrations of Parecoxib and Flunixin meglumine on the in vitro culture of bovine embryos
}

\author{
E.M. Razza ${ }^{1}$, R.A. Satrapa ${ }^{1}$, C.F. Silva ${ }^{1}$, T. Nabhan ${ }^{1}$, R.A.L. Simões ${ }^{1}$, I.P. Emanuelli ${ }^{1}$, J. Mazucheli ${ }^{2}$, \\ C.M. Barros ${ }^{1}$, M.F.G. Nogueira ${ }^{3,4}$ \\ ${ }^{1}$ Department of Pharmacology, São Paulo State University (UNESP), Botucatu, SP, Brazil. \\ ${ }^{2}$ Departament of Statistics, State University of Maringá, Maringá, PR, Brazil. \\ ${ }^{3}$ Department of Biological Sciences, UNESP, Assis, SP, Brazil.
}

\begin{abstract}
Since cyclooxygenase (COX) inhibitors have been pointed out as potential treatments to increase pregnancy rates after embryo transfer, the present experiment aimed to evaluate the effects of flunixin meglumine (FM) and parecoxib (P), a COX-1 and 2 or COX-2 specific inhibitor, respectively, on the development of bovine embryos until the hatched blastocyst stage. In vitro produced bovine embryos were cultured in media with different concentrations of FM $(0.14 ; 1.4 ; 14 ; 140$ or $1400 \mu \mathrm{g} / \mathrm{ml})$ or $\mathrm{P}(0.09 ; 0.9 ; 9 ; 90$ or $900 \mu \mathrm{g} / \mathrm{ml}$ ) and the production rates were evaluated. Concentrations of FM $\leq 14 \mu \mathrm{g} / \mathrm{ml}$ and $\mathrm{P} \leq 90 \mu \mathrm{g} / \mathrm{ml}$ did not impair embryo development, although compiled data from non-lethal FM concentrations $(\leq 14 \mu \mathrm{g} / \mathrm{ml})$ indicated a toxic effect enough to decrease the hatching rate of blastocysts. Concentrations of FM at 140 and $1400 \mu \mathrm{g} / \mathrm{ml}$ and $\mathrm{P}$ at $900 \mu \mathrm{g} / \mathrm{ml}$ were lethal as no cleavage was detected on presumptive zygotes.
\end{abstract}

Keywords: blastocyst, cyclooxygenase inhibitors, drug concentration, embryotoxicity, nonsteroidal antiinflammatory drugs.

\section{Introduction}

The relevance of the steroidal hormone progesterone ( $\mathrm{P} 4)$ on the establishment and maintenance of gestation is well documented (Wilmut et al., 1985; Binelli et al., 2001), as is the relationship between plasma P4 concentrations and the corpus luteum (CL; Lamming et al., 1989; Binelli et al., 2004). Briefly, when the CL is functionally active in the ovary (luteal phase), the concentration of $\mathrm{P} 4$ is high and the uterus is prepared for the establishment of pregnancy (Lamming et al., 1989; Shelton et al., 1990). The conceptus must signal its presence via interferon- $\tau$ production, thus preventing luteolytic prostaglandin F2 $\alpha$ (PGF2 $\alpha$ ) pulses, which results in the maintenance of the CL and the continued release of progesterone (Binelli et al., 2001, 2004; Nogueira et al., 2004). Additionally, reports indicate a negative relationship between PGF2 $\alpha$ concentrations and embryo quality (Schrick et al., 1993;
Buford et al., 1996; Scenna et al., 2004a, b, 2005).

Cyclooxygenase (COX) inhibitors are nonsteroidal anti-inflammatory drugs (NSAIDs) that inhibit PGF2 $\alpha$ synthesis. The resulting antiluteolytic effect of NSAIDs make them potential tools for increasing pregnancy rates after embryo transfer (Binelli et al., 2001, 2004; Schrick et al., 2001). COX exists in two isoforms; COX-1, a constitutive enzyme present in many tissues, and COX-2, an inducible enzyme, mainly produced at the sites of inflammation, and is the key enzyme in the synthesis of PGF2 $\alpha$ by its precursor, arachidonic acid (Thatcher et al., 2001). Flunixin meglumine (FM), a nonselective COX-1/-2 inhibitor, and parecoxib (P), a specific COX-2 inhibitor, could be appropriately used to block COX-2 in an attempt to increase pregnancy rates in the bovine species. However, authors disagree on the concentrations and administration pathways for FM (Buford et al., 1996; Odensvik et al., 1998; Geary et al., 2005; Purcell et al., 2005; Scenna et al., 2005), and the potential side effects of $\mathrm{P}$ have yet to be elucidated (Ayar, 2007).

This study aimed to establish the embryotoxic threshold for concentrations of flunixin meglumine and parecoxib on the in vitro culture of bovine embryos. This approach was previously described to validate a model for pharmacological dose-response (Avery and Schmidt, 1995).

\section{Materials and Methods}

Unless otherwise mentioned, all chemicals were obtained from Sigma-Aldrich Laboratory (St. Louis, MO, USA).

\section{Abattoir location and animals}

Ovaries from the Nelore breed (Bos indicus) were collected from a local abattoir (Frigol, Lençois Paulista, SP, Brazil, latitude $22^{\circ} 35^{\prime} \mathrm{S}$, longitude $48^{\circ} 48^{\prime} \mathrm{W}$ ) located $47 \mathrm{~km}$ from the laboratory (Botucatu, SP, Brazil). The animals came from several different commercial herds and the replicates were performed from January 2007 to June 2008. 
Razza et al. Parecoxib and Flunixin meglumine on embryo culture.

Recovery of cumulus oocyte complexes

Cumulus oocyte complexes (COCs) were aspirated from small follicles (3-8 $\mathrm{mm}$ in diameter) using an 18-ga needle attached to a $10 \mathrm{ml}$ syringe. Oocytes were classified according to their morphology (Khurana and Niemann, 2000) and the ones with a uniformly granulated cytoplasm and surrounded by several (3-4) layers of compact cumulus cells were selected and washed three times with HEPES-buffered TCM-199 medium containing fetal calf serum (FCS, $10 \%$; Gibco, BRL, Burlington, Ontario, Canada), pyruvate $(2 \mu \mathrm{l} / \mathrm{ml}, 100 \mathrm{mM}$ solution) and gentamicin (75 $\mu \mathrm{g} / \mathrm{ml})$ then washed once with maturation medium.

\section{In vitro maturation}

Fifteen to $25 \mathrm{COCs}$ were incubated in groups. Each droplet $(90 \mu \mathrm{l})$ of maturation medium consisted of TCM-199 medium (Earle's salt) supplemented with sodium pyruvate $(2 \mu \mathrm{l} / \mathrm{ml}, 100 \mu \mathrm{mM}$ solution), gentamicin $(75 \mu \mathrm{g} / \mathrm{ml}), \mathrm{pFSH}\left(20 \mu \mathrm{g} / \mathrm{ml}\right.$, Pluset ${ }^{\circledR}$, Serovet, Roma, Italy) and pLH (2 IU/ml, Lutropin ${ }^{\circledR}$, Bioniche, Belleville, Ontario, Canada). The droplets were covered with mineral oil $(3.5 \mathrm{ml})$ and preincubated under the maturation conditions for a minimum of $2 \mathrm{~h}\left(39^{\circ} \mathrm{C}, 5 \% \mathrm{CO}_{2}\right.$ in air with $100 \%$ humidity) then incubated for 18 to $24 \mathrm{~h}$ once the COCs were added.

\section{In vitro fertilization}

In vitro fertilization (IVF) took place in droplets $(90 \mu \mathrm{l})$ containing tyrode albumin lactate pyruvate (TALP) supplemented with $6 \mathrm{mg} / \mathrm{ml}$ fatty acid free BSA, $100 \mathrm{mM}$ sodium pyruvate, $75 \mu \mathrm{g} / \mathrm{ml}$ gentamicin, $11 \mu \mathrm{g} / \mathrm{ml}$ heparin and $44 \mu \mathrm{g} / \mathrm{ml}$ PHE $(2 \mathrm{mM}$ penicillamine, $1 \mathrm{mM}$ hypotaurine and $250 \mathrm{mM}$ epinephrine). Semen was thawed at $37^{\circ} \mathrm{C}$ for $20 \mathrm{~s}$ and spermatozoa were washed in a discontinuous Percoll gradient (Pharmacia, Uppsala, Sweden) prepared by adding $2 \mathrm{ml}$ of $45 \%$ Percoll to $2 \mathrm{ml}$ of $90 \%$ Percoll in a $15 \mathrm{ml}$ centrifuge tube (Corning ${ }^{\circledR} ; 900 \mathrm{~g} ; 30 \mathrm{~min}$ ). After removal of the supernatant, spermatozoa were resuspended in IVF medium $\left(1 \times 10^{6}\right.$ cells $\left./ \mathrm{ml}\right)$ and added into each droplet for incubation $\left(39^{\circ} \mathrm{C} ; 5 \% \mathrm{CO}_{2} ; 10\right.$ to $14 \mathrm{~h})$.

\section{In vitro culture}

Cumulus cells were removed from presumptive zygotes by vortexing the embryos in conical tubes containing TCM-199 medium with HEPES for 4 min. Cumulus-free presumptive zygotes were washed twice in TCM-199 medium with HEPES and transferred to $90 \mu \mathrm{l}$ culture drops (15 to 25 zygotes per drop) under mineral oil. The culture medium consisted of synthetic oviduct fluid with amino acids, sodium citrate and myo-inositol (SOFaaci; Holm et al., $1999)$ plus FCS $\left(5 \%\right.$; Gibco $\left.^{\circledR}\right)$, BSA $(5 \%)$, and sodium pyruvate $(0.2 \%)$, which was used to cultivate the embryos. A submarine incubation system, based on a previous experiment by Satrapa et al. (2011), was used. Briefly, Petri dishes containing embryos were placed in plastic bags $(25 \times 15 \mathrm{~cm})$ containing a gas mixture of $5 \% \mathrm{O}_{2}, 5 \% \mathrm{CO}_{2}$ and $90 \% \mathrm{~N}_{2}$ (White Martins, São Paulo, $\mathrm{SP}$, Brazil). The culture medium was partly replaced with $50 \mu \mathrm{l}$ of fresh medium at 48, 96, 144 and $192 \mathrm{~h}$ after fertilization (Satrapa et al., 2011). Before each medium replacement, cleavage, morula, blastocyst and hatched blastocyst yields were evaluated.

\section{Drug concentrations}

Presumptive zygotes were cultured as described before in the absence (control group) or presence of parecoxib (P; Bextra ${ }^{\circledR}$, injectable, $40 \mathrm{mg}$, Pfizer Pharmaceuticals, Barceloneta, Puerto Rico) or flunixin meglumine (FM; Banamine ${ }^{\circledR}$, injectable, $500 \mathrm{mg}$, Schering-Plough, Rio de Janeiro, Brazil). Standard concentrations were estimated by the usual dosage for embryo transfer in the bovine species $(14 \mu \mathrm{g} / \mathrm{ml} \mathrm{FM}$; Geary et al., 2005; Purcell et al., 2005) and based on the maximum daily dosage of the prescription for a human being (i.e., $80 \mathrm{mg}$ of $\mathrm{P}$, according to drug information contents). The approach to define the $\mathrm{P}$ concentration for the bovine species was attempted using the average body weight of a human being $(70 \mathrm{~kg})$ and bovine $(450 \mathrm{~kg})$. Metabolic weights of humans $\left(\mathrm{MWH}=70^{0.75}\right.$ ) and the bovine $\left(\mathrm{MWB}=450^{0.75}\right.$ ) species were calculated (Keesey and Hirvonen, 1997) and the proportional concentration of $\mathrm{P}$ to $\mathrm{MWH}(80 \mathrm{mg} / 24.2 \mathrm{~kg})$ was calculated for $97.7 \mathrm{~kg}$ of MWB (i.e., approximately $323 \mathrm{mg}$ of P). Bovine blood volume was calculated based on an average body weight of $450 \mathrm{~kg}$ and an average of $8 \%$ blood volume (1) relative to body weight, that is, 361 of blood (Reynolds, 1953; Aird et al., 2006). Finally, P serum concentration in the bovine species was calculated by dividing total dosage $(323 \mathrm{mg})$ by blood volume $(36000 \mathrm{ml})$. The calculated $\mathrm{P}$ serum concentration (approximately $9 \mu \mathrm{g} / \mathrm{ml}$ ) was used as the standard, and it could be the approximate $\mathrm{P}$ concentration of the uterine environment that the bovine embryo would be exposed to under real conditions of drug administration. For both drugs, decreased ( $\mathrm{x} 0.1$ and $\mathrm{x} 0.01)$ and increased (x10 and $\mathrm{x} 100)$ concentrations were calculated relative to the standard $\mathrm{P}$ and $\mathrm{FM}$ concentrations $(0.09 ; 0.9 ; 9 ; 90$ and $900 \mu \mathrm{g} / \mathrm{ml}$ of parecoxib; $0.14 ; 1.4 ; 14 ; 140$ and $1400 \mu \mathrm{g} / \mathrm{ml}$ of FM). During IVC, each culture dish had medium drops with all drug ( $\mathrm{P}$ and $\mathrm{FM}$ ) concentrations along with a control group (without the drug). When the medium was partially changed, the drug concentrations were maintained the same as the original drop concentration. 
Razza et al. Parecoxib and Flunixin meglumine on embryo culture.

A pilot experiment (4 replicates) was performed to evaluate the embryo toxicity of the drug diluent itself $(\mathrm{NaCl} 0.9 \%)$ on bovine blastocyst and hatched blastocyst production. Only the diluents were added to the IVC medium, as the same volume would be used in the several different concentrations and IVC was done the same way as the P, FM and control groups.

\section{Statistical analyses}

Data were compared among concentrations (drug concentrations and respective control, i.e., intradrug comparison) by a Cochran-Armitage Trend Test (Armitage, 1955; Agresti, 2002) and by clustering non-lethal concentrations of the same drug to compare hatched blastocyst rates with their respective control group using Chi-square analysis (Yates correction for continuity). Significance was considered when $\mathrm{P}<0.05$.

\section{Results}

The results show data from 11 replicates for FM and 14 for P. However, for the FM concentrations of 140 and $1400 \mu \mathrm{g} / \mathrm{ml}$ and $\mathrm{P}$ concentration of $900 \mu \mathrm{g} / \mathrm{ml}$, data are from 4 replicates only, since a lethal effect (i.e., arrested embryo development) was observed in these groups.

\section{Parecoxib}

Cleavage, morula, blastocyst and hatched blastocyst rates of all $\mathrm{P}$ concentrations are summarized in Table 1. A concentration of $900 \mu \mathrm{g} / \mathrm{ml}$ was lethal for embryo development as early as the first cleavages (48 $\mathrm{h}$ post insemination). The other concentrations $(0.09 ; 0.9 ; 9$ and $90 \mu \mathrm{g} / \mathrm{ml})$ showed no significant differences in blastocyst and hatched blastocyst rates when compared to the control group.

Table 1. Number of oocytes (n) and cleavage (CLE), morula (MO), blastocyst (BL) and hatched blastocyst (HB) rates after treatment with increasing concentrations of parecoxib or the control.

\begin{tabular}{lccccc}
\hline $\begin{array}{c}\text { Parecoxib } \\
(\mu \mathrm{g} / \mathrm{ml})\end{array}$ & $\begin{array}{c}\text { Oocytes } \\
\mathrm{n}\end{array}$ & $\begin{array}{c}\text { CLE } \\
\mathrm{n}(\%)\end{array}$ & $\begin{array}{c}\text { MO } \\
\mathrm{n}(\%)\end{array}$ & $\begin{array}{c}\text { BL } \\
\mathrm{n}(\%)\end{array}$ & $\begin{array}{c}\text { HB } \\
\mathrm{n}(\%)\end{array}$ \\
\hline Control $(0)$ & 247 & $197(79.8)$ & $148(59.9)$ & $88(35.6)$ & $42(17.0)$ \\
0.09 & 223 & $171(76.7)$ & $127(57.0)$ & $60(26.1)$ & $32(14.4)$ \\
0.9 & 208 & $158(76.0)$ & $110(52.9)$ & $52(25.0)$ & $22(10.6)$ \\
9 & 219 & $156(71.2)$ & $109(49.8)$ & $53(24.2)$ & $31(14.2)$ \\
90 & 205 & $146(71.2)$ & $99(48.3)$ & $49(24.0)$ & $22(10.7)$ \\
900 & 45 & $0(0.0)$ & $0(0.0)$ & NA & NA \\
P- value for trend test* & & 0.1 & 0.05 & 0.16 & 0.19 \\
\hline
\end{tabular}

*Cochran-Armitage Trend Test was performed only with concentrations $\leq 90 \mu \mathrm{g} / \mathrm{ml}$. NA (not applicable) since after evaluation of morula rate, the presumptive zygotes were morphologically dead (dark color and/or fragmented and/or no visible cytoplasmic membrane) and were removed from the culture drops.

\section{Flunixin meglumine}

Cleavage, morula, blastocyst and hatched blastocyst rates of all FM concentrations are summarized in Table 2. The two highest FM concentrations (140 and $1400 \mu \mathrm{g} / \mathrm{ml})$ were lethal for embryo development as early as the first cleavage evaluation. However, the other concentrations had no significant difference when compared to the control group.

Table 2. Number of oocytes (n) and cleavage (CLE), morula (MO), blastocyst (BL) and hatched blastocyst (HB) rates after treatment with increasing concentrations of flunixin meglumine or the control.

\begin{tabular}{lccccc}
\hline $\begin{array}{c}\text { Flunixin Meglumine } \\
(\mu \mathrm{g} / \mathrm{ml})\end{array}$ & $\begin{array}{c}\text { Oocytes } \\
\mathrm{n}\end{array}$ & $\begin{array}{c}\text { CLE } \\
\mathrm{n}(\%)\end{array}$ & $\begin{array}{c}\text { MO } \\
\mathrm{n}(\%)\end{array}$ & $\begin{array}{c}\text { BL } \\
\mathrm{n}(\%)\end{array}$ & $\begin{array}{c}\text { HB } \\
\mathrm{n}(\%)\end{array}$ \\
\hline Control $(0)$ & 124 & $104(83.9)$ & $80(64.5)$ & $49(39.5)$ & $37(29.8)$ \\
0.14 & 123 & $94(76.4)$ & $66(53.7)$ & $35(28.5)$ & $18(14.6)$ \\
1.4 & 122 & $94(77.1)$ & $66(54.1)$ & $35(28.7)$ & $18(14.8)$ \\
14 & 117 & $87(74.4)$ & $70(59.8)$ & $34(29.1)$ & $25(21.4)$ \\
140 & 44 & $0(0.0)$ & $0(0.0)$ & NA & NA \\
1400 & 44 & $0(0.0)$ & $0(0.0)$ & NA & NA \\
P - value for trend test* & & 0.25 & 0.73 & 0.45 & 0.85 \\
\hline
\end{tabular}

*Cochran-Armitage Trend Test was performed only with concentrations $\leq 14 \mu \mathrm{g} / \mathrm{ml}$. NA (not applicable) since after evaluation of morula rate, the presumptive zygotes were morphologically dead (dark color and/or fragmented and/or no visible cytoplasmic membrane) and were removed from the culture drops. 
Razza et al. Parecoxib and Flunixin meglumine on embryo culture.

\section{Pooled data}

The first analysis comparing non-lethal drug concentrations showed no significant difference among themselves $(0.09 ; 0.9 ; 9$ and $90 \mu \mathrm{g} / \mathrm{ml}$ for $\mathrm{P}$, and 0.14 ; 1.4 and $14 \mu \mathrm{g} / \mathrm{ml}$ for FM). Hence, these concentrations were clustered in groups (non-lethal concentrations; nlc) for each drug (nlcP and nlcFM). Control groups from both experiments (Control $\mathrm{P}$ and Control FM) remained as the original control group for each drug and hatched blastocyst rates were compared to the nlcP and nlcFM groups, respectively. There was a statistical difference ( $\mathrm{P}<0.003)$ between hatched blastocyst rates from the nlcFM (16.9\%; 61/362) and Control FM (29.8\%; $37 / 124)$ groups. There was no difference in hatched blastocysts rates $(\mathrm{P}=0.09)$ between the nlcP $(12.5 \%$; $107 / 855)$ and Control P (17.0\%; 42/247) groups.

\section{Discussion}

Some concentrations (FM: $0.14 ; 1.4$ and $14 \mu \mathrm{g} / \mathrm{ml}$; P: $0.09 ; 0.9 ; 9$ and $90 \mu \mathrm{g} / \mathrm{ml})$ did not affect cleavage and blastocyst production. However, higher concentrations (FM: 140 and $1400 \mu \mathrm{g} / \mathrm{ml}$; P: $900 \mu \mathrm{g} / \mathrm{ml}$ ) were lethal, as no presumptive zygotes cleaved under these conditions.

Attempts of FM administration to increase bovine pregnancy rates have already been reported. However, there was no consensus among these studies since in every experiment, neither the dosage, time nor the route of administration were consistent (Buford et al., 1996; Odensvik et al., 1998; Elli et al., 2001; Geary et al., 2005; Purcell et al., 2005; Scenna et al., 2005). Additionally, there is insufficient published information regarding the pharmacological threshold of FM and $\mathrm{P}$ concentrations that may be toxic to bovine embryos. The in vivo use of any drug to modulate embryo development should first be tested for the embryotoxicity threshold using an in vitro model, similar to this study, to facilitate the usage of safe concentrations in vivo. The time that the embryos were exposed to drugs in this study (a maximum of $178 \mathrm{~h}$ on culture) may be considered an extreme condition compared with the shortest time (12 to $24 \mathrm{~h}$ ) of regular treatment in cattle (Buford et al., 1996; Odensvik et al., 1998). Regardless, and despite the unknown bioavailability of these drugs in the bovine uterine lumen, the present assay provides useful information for future in vivo experiments with intramuscular treatments of both FM and $\mathrm{P}$ in the bovine species. The analysis of pooled data from the non-lethal concentrations of $\mathrm{P}$ resulted in no decrease in the hatching rate (178 h of culture) compared with the control group, whereas with the non-lethal concentrations of FM, there was a significant difference between hatched blastocysts compared with the control group (16.9 and 29.8\%, respectively). This finding could be interpreted as being due to the long time that the embryos were exposed to the drug until the hatching stage, and mainly due to the drug itself (i.e., its pharmacological properties) because this effect was not observed $(\mathrm{P}=0.09)$. In a pilot experiment (results not shown), the vehicle used to dilute each drug was tested to evaluate its embryotoxicity, and no apparent harmful effects of the P or FM vehicle were observed. Since individual FM non-lethal concentrations did not differ from the control, it is difficult to infer which concentrations were the main effectors of potential embryotoxicity observed in the pooled data. This presumptive embryotoxicity could have arisen when concentrations were clustered, resulting in a robust sample large enough to produce a statistical difference between pooled FM data and the control. Moreover, the system of bovine IVP itself is a source of great variation in inter replicates (age, body condition, health status of animals), thus, both factors could explain the statistical difference observed only in the pooled FM data.

As previously described, this dose-response study could be the first screening for potential bovine embryotoxic effects of new drugs (usage of $\mathrm{P}$ in bovine embryo transfer). However, embryonic safety needs in vivo validation since unexpected in vivo effects could not be ruled out solely based on an in vitro model of embryotoxicity.

A flunixin meglumine concentration of $14 \mu \mathrm{g} / \mathrm{ml}$ (already employed in vivo as a strategy for increasing pregnancy rates in bovine recipients) was not toxic enough to inhibit the development of cultured bovine embryos, even after a long time of exposure. In addition, high concentrations of $\mathrm{P}(900 \mu \mathrm{g} / \mathrm{ml})$ and FM (140 and $1400 \mu \mathrm{g} / \mathrm{ml}$ ) were lethal as early as the first cleavage, i.e., under the effect of a few hours of drug exposure.

In conclusion, bovine embryo development was completely impaired with concentrations of $900 \mu \mathrm{g} / \mathrm{ml}$ parecoxib and 140 and $1400 \mu \mathrm{g} / \mathrm{ml}$ flunixin meglumine in the culture medium. When the non-lethal concentrations were compared, we inferred that parecoxib had a lower potential toxicity to decrease hatching rates after a long time of drug exposure (178 h) during culture.

\section{Acknowledgments}

Some of the authors have fellowships from FAPESP of Brazil, processes \# 2007/04284-2 (Razza EM), 06/60862-2 (Satrapa RA), 2007/58961-5 (Silva CF), 07/51367-0 (Simões RAL), 2009/10679-5 (Emanueli IP) and 2006/06491-2 and 2007/07705-9 (Nogueira MFG). 


\section{References}

Agresti A. 2002. Categorical Data Analysis. 2nd ed. New York, NY: John Wiley.

Aird B. 2006. Acute blood loss anemia. In: Feldman BU (Ed.). Schalm's Veterinary Hematology. Ames, IA: Blackwell. pp. 151-153.

Armitage P. 1955. Tests for linear trends in proportions and frequencies. Biometrics, 11:375-386.

Avery B, Schmidt M. 1995. A dose-response study of ivermectin in a bovine in vitro production system. Theriogenology, 43:163. (abstract).

Ayar A. 2007. Tocolytic effect of parecoxib, a new parenteral cyclo-oxygenase-2-especific inhibitor, on the spontaneous and prostaglandin-induced contractions of rat isolated myometrium. Clin Exp Pharmacol Physiol, 34:737-741.

Binelli M, Thatcher WW, Mattos R, Baruselli PS. 2001. Antiluteolytic strategies to improve fertility in cattle. Theriogenology, 56:1451-1463.

Binelli M, Machado R, Bergamaschi M, Baruselli PS. 2004. Atualizações sobre estratégias antiluteolíticas para o aumento da fertilidade em bovinos. In: Simpósio Internacional de Reprodução Animal Aplicada, 1, 2004, Londrina, PR. Anais... Londrina, PR: SIRAA. pp. 191198.

Buford WI, Ahmad F, Schrick N, Butcher RL, Lewis PE, Inskeep EK. 1996. Embryotoxicity of a regressing corpus luteum in beef cows supplemented with progestogen. Biol Reprod, 54:531-537.

Elli M, Gaffuri B, Frigerio A, Zanardelli M, Covini D, Candiani M, Vignali, M. 2001. Effect of a single dose of ibuprofen lysinate before embryo transfer on pregnancy rates in cows. J Reprod Fertil, 121:151-154.

Geary TW, Ansotegui RP, Roberts AJ, Waterman RC, MacNeil MD, Grings EE, Thompson BD, Lipsey RJ. 2005. Effects of flunixin meglumine on pregnancy establishment in beef cattle. Proc West Sec Am Soc Anim Sci, 56:309-311.

Holm P, Booth PJ, Schmidt MH, Greve T, Callesen H. 1999. High bovine blastocyst development in a static in vitro production system using SOFaa medium supplemented with sodium citrate and myo-inositol with or without serum-proteins. Theriogenology, 52:683-700.

Keesey RE, Hirvonen MD. 1997. Body weight setpoints: determination and adjustments. $J$ Nutr, 127:1875S-1883S.

Khurana NK, Niemann H. 2000. Effects of oocyte quality, oxygen tension, embryo density, cumulus cells and energy substrates on cleavage and morula/blastocyst formation of bovine embryos. Theriogenology, 54:741756.
Lamming GE, Darwash AO, Black HL. 1989. Corpus luteum function in dairy cows and embryo mortality. $J$ Reprod Fertil, 37:245-252.

Nogueira MFG, Melo DS, Carvalho LM, Fuck EJ, Trinca LA, Barros CM. 2004. Do high progesterone concentrations decrease pregnancy rates in embryo recipients synchronized with PGF2 $\alpha$ and eCG? Theriogenology, 61:1283-1290.

Odensvik K, Gustafsson H, Kindahl H. 1998. The effect on luteolysis by intensive oral administration of flunixin granules in heifers. Anim Reprod Sci, 50:35-44.

Purcell SH, Beal WE, Gray KR. 2005. Effect of a CIDR insert and flunixin meglumine, administered at the time of embryo transfer, on pregnancy rate and resynchronization of estrus in beef cattle. Theriogenology, 64:867-878.

Reynolds M. 1953. Measurement of bovine plasma and blood volume during pregnancy and lactation. Am J Physiol, 175:118-122.

Satrapa RA, Nabhan T, Silva CF, Simões RA, Razza EM, Puelker RZ, Trinca LA, Barros CM. 2011. Influence of sire breed (Bos indicus versus Bos taurus) and interval from slaughter to oocyte aspiration on heat stress tolerance of in vitro-produced bovine embryos. Theriogenology, 76:1162-1167.

Scenna FN, Edwards JL, Rohrbach NR, Hockett ME, Saxton AM, Schrick FN. 2004a. Detrimental effects of prostaglandin F2 alpha on preimplantation bovine embryos. Prostaglandins Other Lipid Mediat, 73:215-226.

Scenna FN, Edwards JL, Schrick FN. 2004 b. Prostaglandin F2- $\alpha$ compromises development of preimplantation bovine embryos during compaction. Reprod Fertil Dev, 16:191-192.

Scenna FN, Hockett ME, Towns TM, Saxton AM, Rohrbach NR, Wherman ME, Schrick FN. 2005. Influence of a prostaglandin synthesis inhibitor administered at embryo transfer on pregnancy rates of recipients cows. Prostaglandins Other Lipid Mediat, 78:38-45

Schrick FN, Inskeep EK, Butcher RL. 1993. Pregnancy rates for embryos transferred from early pospartum beef cows into recipients with normal estrous cycles. Biol Reprod, 49:617-621.

Schrick FN, Hockett ME, Towns TM, Saxton AM, Wert NE, Wehrman ME. 2001. Administration of a prostaglandin inhibitor immediately prior to embryo transfer improves pregnancy rates in cattle. Theriogenology, 55:370. (abstract).

Shelton K, Gayerie D, Abreu MF, Hunter MG, Parkinson TJ, Lamming GE. 1990. Luteal inadequacy during the early luteal phase of subfertile cows. $J$ Reprod Fertil, 90:1-10. 
Razza et al. Parecoxib and Flunixin meglumine on embryo culture.

Thatcher WW, Guzeloglu A, Mattos R, Binelli M, Wilmut I, Sales DI, Ashworth CJ. 1985. The influence Hansen TR, PRU JK. 2001. Uterine-conceptus of variation in embryo stage and maternal hormone interactions and reproductive failure in cattle. profiles on embryo survival in farm animals. Theriogenology, 56:1435-1450.

Theriogenology, 23:107-119. 